\title{
SUBSTITUTION AND PROTONATION REACTIONS OF NITRILOTRIACETATOCHROMIUM(III) IONS
}

\author{
H. G. VISSER, J. G. IEIPOLDT* and W. PURCELL* \\ Department of Chemistry, University of the Orange Free State, Bloemfontein 9300, \\ South Africa \\ and

\section{MOSTERT} \\ Division of Textile Technology, CSIR, P.O. Box 1124, Port Elizabeth 6000, South Africa
}

(Received 24 August 1993; accepted 5 October 1993)

\begin{abstract}
The reaction of $\mathrm{NH}_{4}\left[\mathrm{Cr}(\mathrm{NTA})\left(\mathrm{H}_{2} \mathrm{O}\right)_{2}\right]\left(\mathrm{NTA}=\right.$ nitrilotriacetic acid) with $\mathrm{H}^{+}$ has been studied at different temperatures and a rate constant of $1.27(3) \times 10^{-2} \mathrm{~s}^{-1}$ was obtained at $25.1^{\circ} \mathrm{C}$. It is proposed that the reaction involves the formation of an ion pair, followed by the protonation of one of the carboxylate groups of the NTA ligand bonded to the central metal ion. This results in the formation of the $\left[\mathrm{Cr}\left(\eta^{3}-\mathrm{NTA}\right)\left(\mathrm{H}_{2} \mathrm{O}\right)_{3}\right]^{+}$complex. The substitution reactions between $\left[\mathrm{Cr}(\mathrm{NTA})\left(\mathrm{H}_{2} \mathrm{O}\right)_{2}\right] /\left[\mathrm{Cr}(\mathrm{NTA})(\mathrm{OH})\left(\mathrm{H}_{2} \mathrm{O}\right)\right]^{-}$and different ligands $\left(\mathrm{NCS}^{-}\right.$and $\mathrm{EBT}^{-}: \mathrm{EBT}^{-}=$Eriochrome Black $\left.\mathrm{T}\right)$ were also studied. The secondorder rate constant for the reaction of $\mathrm{NCS}^{-}$with the $\left[\mathrm{Cr}(\mathrm{NTA})\left(\mathrm{H}_{2} \mathrm{O}\right)_{2}\right]$ complex at $35.0^{\circ} \mathrm{C}$ was $9.1(1) \times 10^{-3} \mathrm{M}^{-1} \mathrm{~s}^{-1}$ and that for the reaction of EBT ${ }^{-}$with the metal complex at $30.0^{\circ} \mathrm{C}$ was $9.5(6) \times 10^{-2} \mathrm{M}^{-1} \mathrm{~s}^{-1}$. The increase in substitution rate for the reaction between $\left[\mathrm{Cr}(\mathrm{NTA})\left(\mathrm{H}_{2} \mathrm{O}\right)_{2}\right]$ and $\mathrm{EBT}^{-}$is attributed to the chelation of the $\mathrm{EBT}^{-}$ligand during this reaction.
\end{abstract}

Chromium salts are extensively used as metallic mordants in the dyeing industry due to their positive effect on colourfastness and relative low cost. Residual chromium salts in effluents have, however, become an ecological problem and modifications to existing procedures and new colouring techniques are currently being developed. ${ }^{1,2}$

In most commercial processes chromium is applied by treating the wool with $\mathrm{Cr}_{2} \mathrm{O}_{7}{ }^{2-} / \mathrm{CrO}_{4}{ }^{2-}$ solutions at approximately $100^{\circ} \mathrm{C}$. During this process the chromium(VI) is reduced to chromium(III) by functional groups in the wool-like cysteine and tyrosine, or auxiliary reducing agents such as $\mathrm{S}_{2} \mathrm{O}_{3}{ }^{2-}$ and $\mathrm{HSO}_{3}{ }^{-3,4}$ The chromium(III) ions then react via substitution reactions with both the

*Authors to whom correspondence should be addressed. colouring agent and the functional groups in the wool fibre to form the highly coloured complex attached to the wool fibre via the functional groups of the wool, giving it its colourfastness.

Kinetic studies involving chromium(III) have been extensively investigated and the principal characteristic of most of these results was the relative inertness of these complexes towards substitution reactions. ${ }^{5,6}$ Recent studies, however, have shown that the reactivity of the chromium(III) ion can be improved by orders of magnitude if electrondonating ligands are bonded to the metal ion. Studies have shown that $\left[\mathrm{Cr}(\mathrm{TPPS})\left(\mathrm{H}_{2} \mathrm{O}\right)_{2}\right]^{3-}$ (the TPPS porphyrin is highly electron rich) reacts for example about 2500 times faster with $\mathrm{NCS}^{-}\left(k_{1}=4.7 \times 10^{-3}\right.$ $\left.\mathrm{M}^{-1} \cdot \mathrm{s}^{-1}\right)^{7}$ compared with the reaction between $\left[\mathrm{Cr}\left(\mathrm{H}_{2} \mathrm{O}\right)_{6}\right]^{3+}$ and $\mathrm{NCS}^{-}\left(k_{1}=1.8 \times 10^{-6} \mathrm{M}^{-1} \mathrm{~s}^{-1}\right){ }^{8}$ Another ligand which has the ability to increase 
the reactivity of the chromium(III) ion is nitrilotriacetic acid (NTA). ${ }^{9}$ The NTA ligand acts as a tetradentate ligand, coordinating via a nitrogen and three oxygen atoms to the metal ion. The octahedral geometry of the ion is completed by two aqua ligands, which are $c i s$ bonded in the complex. These features (reactivity and cis aqua ligands) make this complex highly suitable to use as a model complex to study the reactions between chromium(III) and different ligands such as $\mathrm{NCS}^{-}$and colouring agents for wool like Eriochrome Black T (EBT), as well as to investigate its ability to react with wool fibre in an attempt to find alternative chromium(III) mordants.

\section{EXPERIMENTAL}

$\mathrm{NH}_{4}\left[\mathrm{Cr}(\mathrm{NTA})(\mathrm{OH})\left(\mathrm{H}_{2} \mathrm{O}\right)\right] \cdot 2 \mathrm{H}_{2} \mathrm{O}$ was prepared using a method similar to that used by Uehara and co-workers. ${ }^{10}$ The precipitate was obtained by adding ethanol to solutions containing the final product.

The UV-vis spectra were recorded and the reactions monitored on a Hitachi (model 150-20) double-beam spectrophotometer connected to a Fryka-Kaltechnich KB 300-thermostated bath. IR spectra were recorded on a Hitachi (model 270-50) IR spectrophotometer. All $\mathrm{pH}$ measurements were performed on an Orion (model 701) $\mathrm{pH}$ meter, using potassium hydrogen phthalate and potassium dihydrogen phosphate/disodium hydrogen phosphate as buffer solutions. ${ }^{11}$

The kinetics were studied under pseudo-firstorder conditions. Linear plots of $\log \left(A_{\infty}-A_{\mathfrak{t}}\right)$ vs time were obtained for at least two half-lives under all conditions. All measurements (except for EBT as a ligand) were performed at a constant ionic strength of $1.0 \mathrm{M}\left(\mathrm{NaNO}_{3}\right)$ after ensuring that the nitrate ions do not labilize the chromium complex. The rate and equilibrium constants were calculated with a 386-personal computer using a non-linear leastsquares program.

\section{RESULTS AND DISCUSSION}

\section{Reaction with $\mathrm{H}^{+}$}

The $\left[\mathrm{Cr}(\mathrm{NTA})\left(\mathrm{H}_{2} \mathrm{O}\right)_{2}\right] \quad\left(\mathrm{p} K_{\mathrm{a}}=5.47\right)^{9}$ complex was obtained by acidifying a $[\mathrm{Cr}(\mathrm{NTA})(\mathrm{OH})$ $\left.\left(\mathrm{H}_{2} \mathrm{O}\right)\right]^{-}$solution. A slow change in the $\mathrm{UV}-$ vis spectra was observed at low $\mathrm{pH}$ values $(\mathrm{pH}<1.0)$, which did not correspond to normal protonation reactions. Substitution reactions with different ligands (anions) at these $\mathrm{pH}$ values were eliminated by the study of the reactions between $[\mathrm{Cr}$
Table 1. Observed rate constants for the reaction between $\left[\mathrm{Cr}(\mathrm{NTA})\left(\mathrm{H}_{2} \mathrm{O}\right)_{2}\right]$ and different acids and anions

\begin{tabular}{lc}
\hline \multicolumn{1}{c}{ Reactant } & $\begin{array}{c}\left(10^{3}\right) k_{\text {obs }} \\
\left(\mathrm{s}^{-1}\right)\end{array}$ \\
\hline $0.2 \mathrm{M} \mathrm{HCl}$ & $5.38(4)$ \\
$0.2 \mathrm{M} \mathrm{HCl}+0.4 \mathrm{M} \mathrm{NaCl}$ & $5.55(4)$ \\
$0.2 \mathrm{M} \mathrm{HClO}$ & $5.44(3)$ \\
$0.4 \mathrm{M} \mathrm{HCl}$ & $7.99(2)$ \\
\hline
\end{tabular}

(NTA) $\left(\mathrm{H}_{2} \mathrm{O}\right)_{2}$ ] and strong acids with non-coordinating anions, see Table 1.

A study of the reactions between [Cr(NTA) $\left(\mathrm{H}_{2} \mathrm{O}\right)_{2}$ ] and $\mathrm{H}^{+}$at different temperatures showed non-linear kinetics, see Fig. 1, and the following mechanism is proposed for the observed kinetics:

K

$\left[\mathrm{Cr}\left(\eta^{4}-\mathrm{NTA}\right)\left(\mathrm{H}_{2} \mathrm{O}\right)_{2}\right]+\mathrm{H}^{+} \longrightarrow\left[\mathrm{Cr}\left(\eta^{4}-\mathrm{NTA}\right)\left(\mathrm{H}_{2} \mathrm{O}\right)_{2} \cdot \cdot \mathrm{H}^{+}\right]$

(fast)

$k_{1}$

$\left[\mathrm{Cr}\left(\eta^{4}-\mathrm{NTA}\right)\left(\mathrm{H}_{2} \mathrm{O}\right)_{2} \cdots \mathrm{H}^{+}\right] \longrightarrow\left[\mathrm{Cr}\left(\eta^{3}-\mathrm{NTA}\right)\left(\mathrm{H}_{2} \mathrm{O}\right) 3\right]^{+}$

$$
+\mathrm{H}_{2} \mathrm{O}
$$

(slow)

Scheme 1.

The observed rate law according to the above mechanism is as follows:

$$
k_{\mathrm{obs}}=\left(k K\left[\mathrm{H}^{+}\right]\right) /\left(1+K\left[\mathrm{H}^{+}\right]\right) \text {. }
$$

Rewriting eq. (1) yields eq. (2), which predicts a straight line with a slope $1 / k K$ and intercept $1 / k$ :

$$
1 / k_{\mathrm{obs}}=1 / k K\left[\mathrm{H}^{+}\right]+1 / k \text {. }
$$

The results in Fig. 1 were fitted to eq. (2) and a straight line was obtained. The calculated $k$ and $K$ values, as well as the activation parameters (using the Eyring-Polanyi equation), are reported in Table 2.

The mechanism which is proposed for this reac-

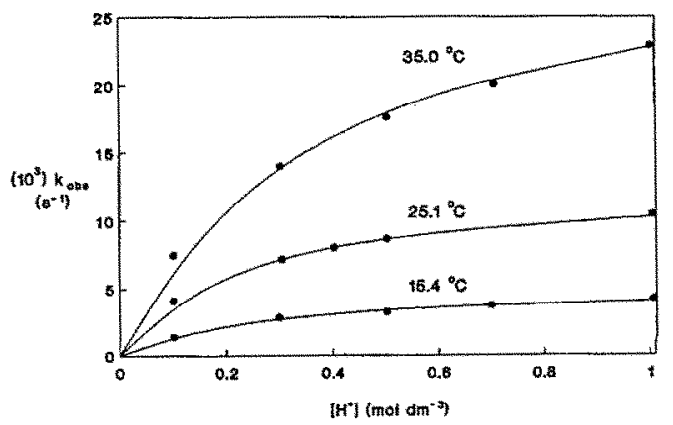

Fig. 1. Plot of $k_{\text {obs }}$ vs $\left[\mathrm{H}^{+}\right], \mu=1.0 \mathrm{~mol} \mathrm{dm} \mathrm{m}^{-3}$ and $\lambda=$ $550 \mathrm{~nm}$. 
Table 2. Summary of the rate and stability constants and activation parameters for the reactions between

$\left[\mathrm{Cr}(\mathrm{NTA})\left(\mathrm{H}_{2} \mathrm{O}\right)_{2}\right]$ and various ligands

\begin{tabular}{|c|c|c|c|c|c|c|c|c|c|}
\hline \multirow[b]{2}{*}{ Temperature $\left({ }^{\circ} \mathrm{C}\right)$} & \multicolumn{3}{|c|}{$\mathbf{H}^{+a}$} & \multicolumn{3}{|c|}{$\mathrm{NCS}^{-b}$} & \multicolumn{3}{|c|}{ EBT $^{--}$} \\
\hline & 15.4 & 25.1 & 35.0 & 25.0 & 35,0 & 45.0 & 30.0 & 40.0 & 50.0 \\
\hline $\begin{array}{l}\left(10^{3}\right) k^{d} \\
\left(\mathrm{~s}^{-1}\right)\end{array}$ & $5.2(2)$ & $12.7(3)$ & $31.7(2)$ & & & & & & \\
\hline $\begin{array}{l}\left(10^{3}\right) k_{\mathrm{le}} \\
\left(\mathrm{M}^{-1} \mathrm{~s}^{-1}\right)\end{array}$ & & & & $5.8(2)$ & $9.1(1)$ & $16.5(4)$ & $95(6)$ & $260(10)$ & $630(8)$ \\
\hline $\begin{array}{l}\left(10^{3}\right) k_{1}{ }^{\prime} \\
\left(\mathrm{s}^{-1}\right)\end{array}$ & & & & $1.25(8)$ & $1.78(9)$ & $3.8(2)$ & $0.52(2)$ & $1.59(5)$ & $3.36(5)$ \\
\hline $\begin{array}{l}\left(10^{3}\right) k_{2}^{f} \\
\left(\mathrm{M}^{-1} \mathrm{~s}^{-1}\right)\end{array}$ & & & & & $23.0(3)$ & & & & \\
\hline $\begin{array}{l}\left(10^{3}\right) k_{-2}^{g} \\
\left(\mathrm{~s}^{-1}\right)\end{array}$ & & & & & $10.3(3)$ & & & & \\
\hline$K\left(\mathrm{M}^{-1}\right)^{d}$ & $3.7(4)$ & $4.3(4)$ & $2.6(4)$ & & & & $3.7(4)$ & $4.3(4)$ & $2.6(4)$ \\
\hline$K_{1}\left(\mathrm{M}^{-1}\right)^{h}$ & & & & $4.62(3)$ & $5.11(3)$ & $4.34(3)$ & $182(13)$ & $167(8)$ & $186(8)$ \\
\hline$K_{1}\left(\mathrm{M}^{-1}\right)^{i}$ & & & & $5(1)$ & $6(2)$ & $8(2)$ & & $210(67)$ & \\
\hline$\Delta H \ddagger\left(\mathrm{kJ} \mathrm{mol}^{-1}\right)$ & & $65.9(5)$ & & & $39(5)$ & & & $74(2)$ & \\
\hline$\Delta S \ddagger\left(\mathrm{J} \mathrm{mol}{ }^{-1}\right)$ & & $-147(5)$ & & & $-158(8)$ & & & $-18.8(3)$ & \\
\hline
\end{tabular}

${ }^{a}$ See Scheme 1,

${ }^{b}$ See Scheme 2.

' See Scheme 3.

${ }^{d}$ Equation (1).

Equation (5).

${ }^{f}$ Equation (6).

${ }^{g}$ Equation (4).

${ }^{h}$ Equation (3).

${ }^{i} K_{1}=k_{1} / k_{-1}$.

tion involves the formation of an ion pair. Protonation of one of the carboxylate groups of the NTA atoms then occurs, which results in the dissociation of this bond to give the tridentate NTA complex $\left[\mathrm{Cr}\left(\eta^{3}-\mathrm{NTA}\right)\left(\mathrm{H}_{2} \mathrm{O}\right)_{3}\right]^{+}$.

\section{Reaction with $\mathrm{NCS}^{-}$}

The substitution reaction between [Cr(NTA) $\left.\left(\mathrm{H}_{2} \mathrm{O}\right)_{2}\right] /\left[\mathrm{Cr}(\mathrm{NTA})(\mathrm{OH})\left(\mathrm{H}_{2} \mathrm{O}\right)\right]^{-}$and $\mathrm{NCS}^{-}$was studied at $\mathrm{pH}$ values between 3 and 6 . At these $\mathrm{pH}$ values, where both chromium(III) species can react with $\mathrm{NCS}^{-}$, the following reaction scheme is proposed:

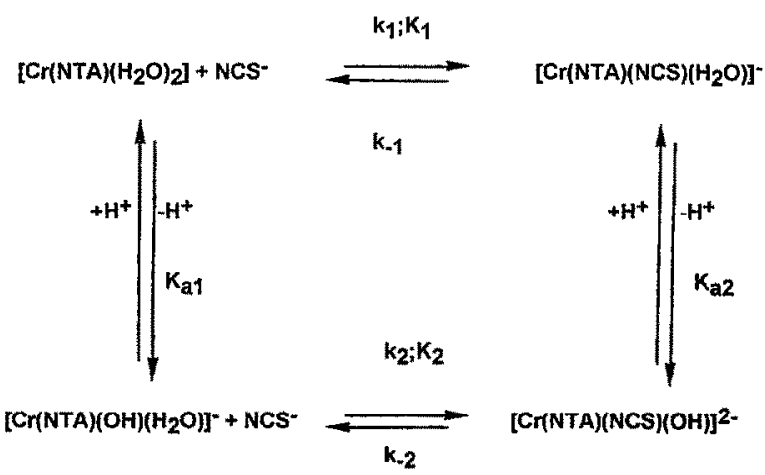

Scheme 2.
The stability constants of $\left[\mathrm{Cr}(\mathrm{NTA})(\mathrm{NCS})\left(\mathrm{H}_{2} \mathrm{O}\right)\right]^{-}$ were determined spectrophotometrically at $\mathrm{pH} 3.6$. At this $\mathrm{pH}$ the only chromium(III) species present are $\left[\mathrm{Cr}(\mathrm{NTA})\left(\mathrm{H}_{2} \mathrm{O}\right)_{2}\right]$ and $\left[\mathrm{Cr}(\mathrm{NTA})(\mathrm{NCS})\left(\mathrm{H}_{2} \mathrm{O}\right)\right]^{-}$. From the definition of $K$ (see reaction scheme), Beer's law and mass balance, eq. (3) can be derived

$$
\left.A=\left(A_{\mathrm{M}}+A_{\mathrm{ML}} K_{1}\left[\mathrm{NCS}^{-}\right]\right) /\left(1+K \mathrm{NNCS}^{-}\right]\right) \text {. }
$$

$A$ is the absorbance at a given concentration of $\mathrm{NCS}^{-}, A_{\mathrm{M}}$ and $A_{\mathrm{ML}}$ are the absorbances of $\left[\mathrm{Cr}(\mathrm{NTA})\left(\mathrm{H}_{2} \mathrm{O}\right)_{2}\right]$ and $\left[\mathrm{Cr}(\mathrm{NTA})(\mathrm{NCS})\left(\mathrm{H}_{2} \mathrm{O}\right)\right]^{-}$, respectively. The absorbance vs $\left[\mathrm{NCS}^{-}\right]$data were fitted to eq. (3) and the calculated $K_{\mathrm{t}}$ - values are reported in Table 2.

According to the reaction scheme the observed pseudo-first-order rate constant is given by eq. (4) :

$$
\begin{array}{r}
k_{\mathrm{obs}}=\left\{\left(k_{1}\left[\mathrm{H}^{+}\right]+k_{2} K_{\mathrm{a} 1}\right) /\left(\left[\mathrm{H}^{+}\right]+K_{\mathrm{a} 1}\right)\right\}\left[\mathrm{NCS}^{-}\right] \\
+\left(k_{-1}\left[\mathrm{H}^{+}\right]+k_{-2} K_{\mathrm{a} 2}\right) /\left(\left[\mathrm{H}^{+}\right]+K_{\mathrm{a} 2}\right) .
\end{array}
$$

Equation (4) simplifies at $\mathrm{pH} 3.6$ to eq. (5):

$$
k_{\mathrm{obs}}=k_{1}\left[\mathrm{NCS}^{-}\right]+k_{-1} \text {. }
$$

Plots of $k_{\mathrm{obs}}$ vs [NCS ${ }^{-}$] data at pH 3.6 were linear (see Fig. 2) and the $k_{1}$ and $k_{-1}$ values were calculated using a non-linear least-squares program, see Table 2. 


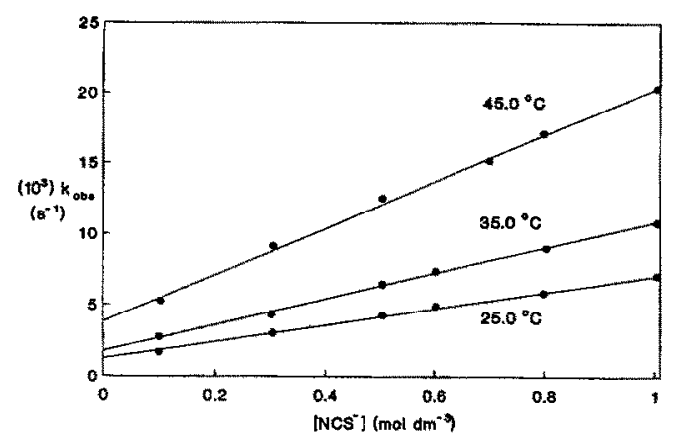

Fig. 2. Plot of $k_{\mathrm{obs}}$ vs [NCS $\left.{ }^{-}\right], \mathrm{pH}=3.6, \lambda=550 \mathrm{~nm}$ and $\mu=1.0 \mathrm{~mol} \mathrm{dm}^{-3}$.

$\left[\mathrm{Cr}(\mathrm{NTA})(\mathrm{OH})\left(\mathrm{H}_{2} \mathrm{O}\right)^{-}\right]$will, according to the reaction scheme (Scheme 2), increase with an increase in pH. The results in Fig. 3 clearly show an increase in substitution rate with an increase in $\mathrm{pH}$. Precipitate formation at $\mathrm{pH}$ values greater than 5.9 prevented the study of these reactions at higher $\mathrm{pH}$. The $k_{2}$ value was calculated from the slope of the plot of $k_{\mathrm{obs}}$ vs $\left[\mathrm{NCS}^{-}\right.$] data at pH 5.85 using eq. (6). At this $\mathrm{pH}$ the slope of this plot is represented by eq. (6):

$$
\text { Slope }=\left(k_{\mathrm{l}}\left[\mathrm{H}^{+}\right]+k_{2} K_{\mathrm{a} 1}\right) /\left(\left[\mathrm{H}^{+}\right]+K_{\mathrm{al}}\right) .
$$

The values of $k_{-2}$ and $K_{\mathrm{a} 2}$ were calculated by fitting the data in Fig. 3 (using $k_{1}, k_{-1}, k_{2}$ and $K_{a 1}$ values already determined) to eq. (4). The results are presented in Table 2.

The second-order rate constant of $5.8 \times 10^{-3}$ $\mathrm{M}^{-1} \mathrm{~s}^{-1}$ at $25^{\circ} \mathrm{C}$ for the reaction between $[\mathrm{Cr}$ (NTA) $\left(\mathrm{H}_{2} \mathrm{O}\right)_{2}$ ] and $\mathrm{NCS}^{-}$compares favourably with the $k_{1}$ value of $4.7 \times 10^{-3} \mathrm{M}^{-1} \mathrm{~s}^{-1}$, which was obtained for the reaction between [Cr(TPPS) $\left.\left(\mathrm{H}_{2} \mathrm{O}\right)_{2}\right]^{3-}$ and $\mathrm{NCS}^{-}$and clearly demonstrates the labilizing effect of the NTA ligand.

The $\left[\mathrm{Cr}(\mathrm{NTA})(\mathrm{OH})\left(\mathrm{H}_{2} \mathrm{O}\right)\right]^{-}$complex reacts about eight times faster with $\mathrm{NCS}^{-}$than

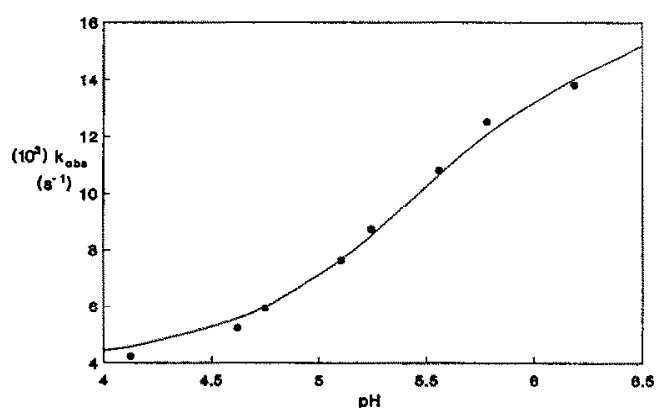

Fig. 3. Plot of $k_{\mathrm{obs}}$ vs pH at $34.2^{\circ} \mathrm{C},\left[\mathrm{NCS}^{-}\right]=0.25 \mathrm{~mol}$ $\mathrm{dm}^{-3}, \lambda=570 \mathrm{~nm}$ and $\mu=1.0 \mathrm{~mol} \mathrm{dm}^{-3}$.
$\left[\mathrm{Cr}(\mathrm{NTA})\left(\mathrm{H}_{2} \mathrm{O}\right)_{2}\right]$ with $\mathrm{NCS}^{-}$. This labilizing effect of the hydroxo ligand is not nearly as profound as in the case of the $\left[\mathrm{Cr}(\mathrm{TPPS})\left(\mathrm{H}_{2} \mathrm{O}\right)_{2}\right]^{3-1}$ $\left[\mathrm{Cr}(\mathrm{TPPS})(\mathrm{OH})\left(\mathrm{H}_{2} \mathrm{O}\right)\right]^{4-}$ complexes (a 6000 times increase in substitution rate was observed). ${ }^{7}$ This much smaller labilizing effect of the hydroxo ligand in the NTA ligand compared with TPPS may be attributed to the fact that the hydroxo and aqua ligands in $\left[\mathrm{Cr}(\mathrm{NTA})(\mathrm{OH})\left(\mathrm{H}_{2} \mathrm{O}\right)\right]^{-}$are cis-bonded to one another and it is well known that a cis effect is usually much smaller than a trans effect. The large negative $\Delta S_{\ddagger}^{\ddagger}$ value suggests an associative activation.

\section{Reaction with Eriochrome Black T}

The reaction between $\left[\mathrm{Cr}(\mathrm{NTA})(\mathrm{OH})\left(\mathrm{H}_{2} \mathrm{O}\right)\right]^{-} /$ $\left[\mathrm{Cr}(\mathrm{NTA})\left(\mathrm{H}_{2} \mathrm{O}\right)_{2}\right]$ and Eriochrome Black T (EBT) was also studied at $\mathrm{pH}$ between 3 and 6 . The $\mathrm{pH}$ at which wool is usually coloured is in this range. Since the $\mathrm{p} K_{\mathrm{a} 1}$ value of $\left[\mathrm{Cr}(\mathrm{NTA})\left(\mathrm{H}_{2} \mathrm{O}\right)_{2}\right]$ and EBT are 5.47 and $6.3,{ }^{11}$ respectively, there are two reactive chromium(III) species and two reactive EBT species present at this pH, see Scheme 3.

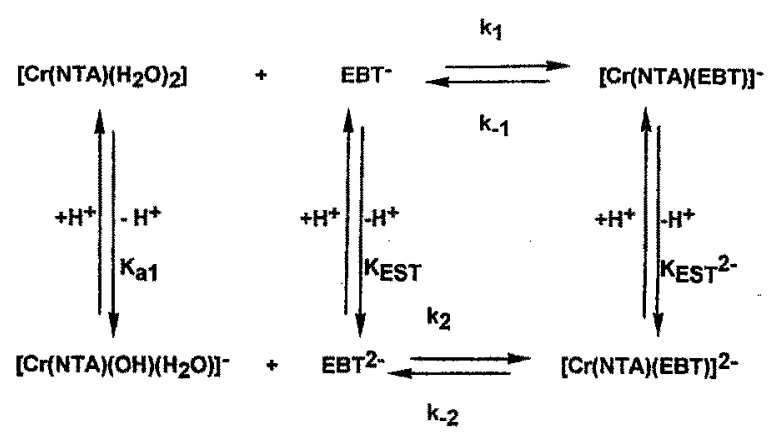

Scheme 3.

These reactions were performed with $\left[\mathrm{Cr}(\mathrm{NTA})\left(\mathrm{H}_{2} \mathrm{O}\right)_{2}\right] \gg\left[\mathrm{EBT}^{-}\right]$due to the colour intensity of $\mathrm{EBT}^{-}$solutions to ensure pseudo-firstorder conditions. In order to simplify the study, the reactions were first performed at $\mathrm{pH}$ 4.0. At this $\mathrm{pH}$, $\left[\mathrm{Cr}(\mathrm{NTA})\left(\mathrm{H}_{2} \mathrm{O}\right)_{2}\right]$ and $\mathrm{EBT}^{-}$are the main species in the solution and the reaction scheme simplifies to eq. (7):

$$
\begin{aligned}
& {\left[\mathrm{Cr}(\mathrm{NTA})\left(\mathrm{H}_{2} \mathrm{O}\right)_{2}\right]+\mathrm{EBT}^{-} } \stackrel{k_{1}}{\underset{k_{-1}}{\leftrightarrows}} \\
& {[\mathrm{Cr}(\mathrm{NTA})(\mathrm{EBT})]^{-} . }
\end{aligned}
$$

The reaction proceeds probably via two steps: one water molecule is substituted in the rate-determining step while the second water molecule is substituted during the fast and ring-closure step.

The stability constant of $[\mathrm{Cr}(\mathrm{NTA})(\mathrm{EBT})]^{-}$was determined spectrophotometrically by fitting absorbance vs $\left[\mathrm{Cr}(\mathrm{NTA})\left(\mathrm{H}_{2} \mathrm{O}\right)_{2}\right]$ data to a modified 


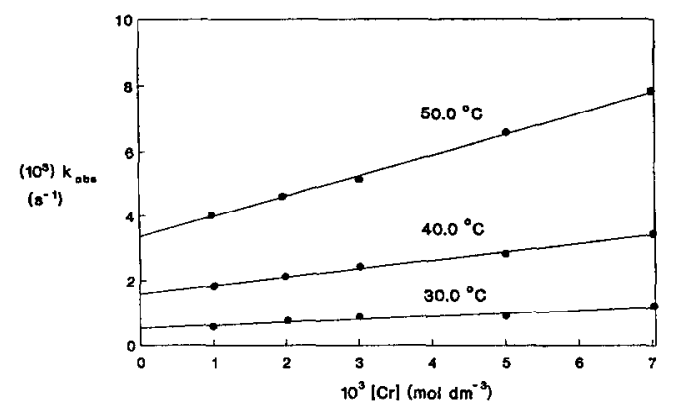

Fig. 4. Plot of $k_{\text {obs }}$ vs $\left[\mathrm{Cr}(\mathrm{NTA})\left(\mathrm{H}_{2} \mathrm{O}\right)_{2}\right], \mathrm{pH}=4.0$ and $\lambda=680 \mathrm{~nm}$.

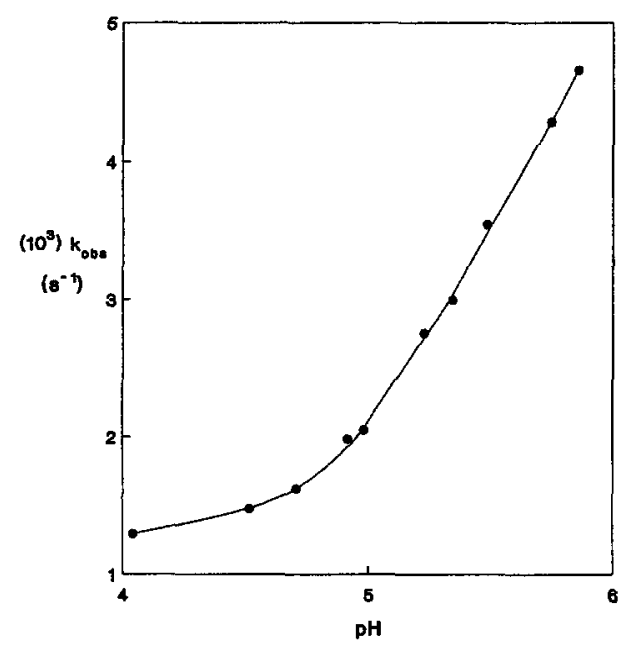

Fig. 5. Plot of $k_{\text {obs }}$ vs pH at $35.0^{\circ} \mathrm{C}$, [Cr(NTA $\left.\left(\mathrm{H}_{2} \mathrm{O}\right)_{2}\right]=$ $0.005 \mathrm{~mol} \mathrm{dm}^{-3}$ and $\lambda=680 \mathrm{~nm}$.

version of eq. (3), see Table 2. According to eq. (8) the pseudo-first-oroter rate constam is given by eq. (8):

$$
k_{\text {obs }}=k_{1}\left[\mathrm{Cr}(\mathrm{NTA})\left(\mathrm{H}_{2} \mathrm{O}\right)_{2}\right]+k_{-1} .
$$

The $k_{\text {obs }}$ vs [Cr(NTA $\left(\mathbf{H}_{2} \mathrm{O}\right)_{2}$ ] data are presented in Fig. 4 and the calculated $k_{1}$ and $k_{-1}$ rate constants are reported in Table 2 . The activation parameters were calculated using the Eyring-Polanyi equation, see Table 2.

It is clear from the reaction scheme that an increase in pH will increase the concentrations of both [Cr(NTA)(OH) $\left.\left(\mathrm{H}_{2} \mathrm{O}\right)\right]^{-}$and $\mathrm{EBT}^{2-}$ and Fig. 5 shows, as was the case for the reaction between $\left[\mathrm{Cr}(\mathrm{NTA})\left(\mathrm{H}_{2} \mathrm{O}\right)_{2}\right] /\left[\mathrm{Cr}(\mathrm{NTA})(\mathrm{OH})\left(\mathrm{H}_{2} \mathrm{O}\right)\right]^{-}$and
$\mathrm{NCS}^{-}$, an increase in substitution rate with an increase in $\mathrm{pH}$, illustrating the cis labilizing effect of the hydroxo ligand. Precipitation formation at $\mathrm{pH}$ values greater than 5.7 prevented the complete study of these reactions at higher $\mathrm{pH}$.

The reaction between $\left[\mathrm{Cr}(\mathrm{NTA})\left(\mathrm{H}_{2} \mathrm{O}\right)_{2}\right]$ and EBT $^{-}$is about 16 times faster $\left(9.5 \times 10^{-2} \mathrm{M}^{-1} \mathrm{~s}^{-1}\right.$ at $30^{\circ} \mathrm{C}$ ) than the corresponding reaction between $\left[\mathrm{Cr}(\mathrm{NTA})\left(\mathrm{H}_{2} \mathrm{O}\right)_{2}\right.$ ] and $\mathrm{NCS}^{-}\left(5.8 \times 10^{-3}\right.$ at $\left.25^{\circ} \mathrm{C}\right)$ and about 20 times faster than the reaction between $\left[\mathrm{Cr}(\mathrm{TPPS})\left(\mathrm{H}_{2} \mathrm{O}\right)_{2}\right]^{3-}$ and $\mathrm{NCS}^{-}$. This increase in substitution rate is attributed to the chelation of the EBT $^{-}$ligand during this reaction. The increase in substitution rate with an increase in $\mathrm{pH}$ is attributed to the cis labilizing effect of the hydroxo ligand in $\left[\mathrm{Cr}(\mathrm{NTA})(\mathrm{OH})\left(\mathrm{H}_{2} \mathrm{O}\right)\right]^{-}$.

The increase in stability $\left(K_{1}=180 \quad \mathrm{M}\right)$ of [Cr(NTA)(EBT) ${ }^{-}$compared with [Cr(NTA)(NCS) $\left.\left(\mathrm{H}_{2} \mathrm{O}\right)\right]^{-}\left(K_{1}=4.60\right)$ is also attributed to chelation.

Acknowledgements - We thank the Division of Textile Technology of the South African C.S.I.R., the Foundation for Research and Development of the South African C.S.I.R. as well as the Research Fund of this university for financial support.

\section{REFERENCES}

1. B. Kramrich, American Dyestuff Reporter, 24 (March 1983).

2. B. Kramrich, Wool Record, 35 (December 1986).

3. S. B. Sello, Proceedings of the 7th International Wool Textile Research Conference V, 109 (1985).

4. P. A. Duffield, Textile Technology, Technical Information Bulletin (November 1988).

5. Advanced Inorganic Chemistry (Edited by F. Cotton and G. Wilkinson), 3rd edn. Interscience Publishers, New York (1966).

6. K. F. Purceil and' $\mathbf{d}$. $\mathcal{C}$. Kotz, Inorganic Chemistry Hoit-Saunders Internationaì Eäitions, Hong Kong (1977).

7. K. R. Ashley, I. G. Leipoldt and V. K. Joshi, Inorg Chem. 1980, 19, 1608.

8. D. Thusius, Inorg Chem. 1971, 10, 1106.

9. Z. Haulin and X.Xu, Polyhedron 1990, 9, 137.

i0. A. Uehara, E. Kyuna and $\mathbf{R}$. Tsuchya, Bull Chem. Soc. Japan 1976, 40, 2322.

11. Vogel's Textbook of Quantitative Inorganic Analysis, 4th edn. Longman Group Limited, London (1978). 